\title{
Differences between root and stem wood in seedlings and sprouts of Sessea brasiliensis (Solanaceae)
}

\author{
Eduardo Luiz Longui ${ }^{1,4}$, Julia Sonsin ${ }^{2}$, Michelle Santos ${ }^{1}$, Frederico Alexandre Roccia Dal Pozzo Arzolla ${ }^{3}$, \\ Francisco Eduardo Silva Pinto Vilela ${ }^{3}$, Israel Luiz de Lima ${ }^{1}$, Sandra Monteiro Borges Florsheim ${ }^{1}$ \& \\ Fernando Descio $^{3}$
}

\begin{abstract}
Young Sessea brasiliensis trees derived from seeds and sprouts after coppicing were analyzed for differences in axial variation of anatomical features. It was hypothesized that 1) quantitative variation in anatomical features in the axial direction would indicate adjustments in water conductivity and mechanical strength along tree height and 2) significant quantitative differences in anatomical features would be observed between trees originating from seed compared to those derived from sprouts after coppicing. Results showed that wood originating from sprouts after coppicing developed differently from wood originating from seeds. Specifically, for seed provenance samples, narrower vessels were observed in the transition zone, whereas for sprouting provenance, narrower vessels were seen in roots and trunk base. Also, when comparing axial variation between seeds and sprouts, vessel diameter was smaller in plants of seed origin in the transition zone, whereas fiber diameter was smaller in trunk top and branch in plants of seed and sprouting provenances, respectively. Higher rays were observed in branch and trunk top when comparing different axial position in both origins. Thus, the first hypothesis is confirmed by significant axial variation in vessels, fibers and rays, and the second hypothesis is confirmed by the significant differences observed between trees of seed and sprout origins.
\end{abstract}

Key words: Cestrum toledoi, ecological wood anatomy, hydraulic conductivity, peroba-d'água, tropical woods.

\section{Resumo}

Analisamos diferenças anatômicas da madeira no sentido axial em árvores jovens de Sessea brasiliensis provenientes de sementes e de brotação após corte raso. Hipotetizamos que 1) a variação anatômica quantitativa na direção axial indicaria ajustes na condutividade hidraúlica e resistência mecânica ao longo da altura da árvore e 2) há diferenças anatômicas significativas entre as árvores provenientes de sementes, quando comparadas àquelas provenientes de brotação após corte raso. Vasos mais estreitos ocorreram na zona de transição nas amostras provenientes de sementes, e nas raízes e base do tronco nas provenientes de brotação; comparando as duas origens, vasos mais estreitos ocorreram na zona de transição das plantas originadas por sementes. Fibras com menores diâmetros ocorreram no topo do tronco e ramo nas amostras provenientes de sementes e rebrota, respectivamente. Raios mais altos ocorreram no topo do tronco e ramo. Os resultados confirmaram nossas hipóteses, com variação axial em vasos, fibras e raios e diferenças anatômicas entre as plantas originadas por sementes e rebrota.

Palavras-chave: Cestrum toledoi, anatomia ecológica da madeira, condutividade hidráulica, peroba-d'água, madeiras tropicais.

\footnotetext{
${ }^{1}$ Instituto Florestal, Divisão de Dasonomia, R. do Horto 931, 02377-000, São Paulo, SP, Brazil.

${ }^{2}$ Universidade de Brasília - UNB, Campus Universitário Darcy Ribeiro, Inst. Ciências Biológicas, Asa Norte, 70910-900, Brasília, DF, Brazil.

${ }^{3}$ Instituto Florestal, Divisão de Reservas e Parques Estaduais, R. do Horto 931, 02377-000, São Paulo, SP, Brazil.

${ }^{4}$ Author for correspondence: edulongui@gmail.com
} 


\section{Introduction}

Sessea brasiliensis Toledo (Solanaceae, synonym: Cestrum toledoi Carvalho \& Schoor) is a tree species native to southeastern Brazil, particularly the states of Minas Gerais and São Paulo (Carvalho \& Schoor 1998; BFG 2015). S. brasiliensis, popularly known as peroba d'água, is adapted to high sunlight and wind dispersal of seeds. It occurs in the initial and intermediary phases of tropical forest succession, occupying the canopy in secondary forests. Its fruits and buds are toxic, especially to grazing cattle (Canella et al. 1968).

Studying clearings of a tropical wet forest in the Parque Estadual Cantareira (PEC), Arzolla (2011) identified 77 species, belonging to 35 families, where the vegetation was cut. Sessea brasiliensis was one of the species with the highest abundance and cover value, similar to Cupania oblongifolia (Sapindaceae) and Guarea macrophylla ssp. tuberculata (Meliaceae). A robust species, Sessea brasiliensis produces long spreading roots, which give rise to independent trunks.

Hydraulic architecture of xylem is reflective of safety and/or efficiency in water conduction, which is mainly regulated by vessel diameter, frequency and length. However, attributes, such as vessel wall thickness, intervessel pit arrangement, size and porosity, also affect water conduction (Hacke et al. 2006; Sperry et al. 2006; Choat et al. 2008). Variation throughout the plant provides for and improves the distribution of water flow to minimize cavitation from roots to crown (Hacke \& Sperry 2001). Studies have recently focused on the variation of axial conductive elements in trees in an attempt to explain how xylem is structured to provide hydraulic efficiency from the roots to leaves (Anfodillo et al. 2013). For some Cerrado plant species, records show structural variation between root and trunk, possibly related to their functional differences (Machado et al. 1997; Goulart \& Marcati 2008; Longui et al. 2012).

Tree roots perform several functions simultaneously, in particular, mechanical support and the acquisition of nutrients and water (ChristensenDalsgaard et al. 2007). For water conduction, vessel diameter typically tends to be larger in roots than trunk, but larger in trunks than branches, in the axial direction (Zimmermann 1978, 1983). Cerrado species are known to have roots that are much deeper than those of species inhabiting other Brazilian biomes, but wall thickness of the fibers is usually the same as that of the main trunk (Machado et al. 1997; Goulart \& Marcati 2008). Nevertheless, few studies have taken into account the mechanical and hydraulic characteristics of roots or root tissue simultaneously, and the effect adaptations with respect to one may have on the other (Christensen-Dalsgaard et al.2007).

From an ecological perspective, sprouting is very important for reforestation (Rodrigues et al. 2004; Van Bloem et al. 2007). It is a natural mechanism of regenerating species commonly found in tropical rain forests that have been subjected to man-made disturbances, such as clear-cutting and forest fires, or natural disturbances, such as strong prevailing winds (Castellani \& Stubblebine 1993; Negrelle 1995; Kammesheidt 1998; Rodrigues et al. 2004; Arzolla 2011). In some species, such as Eucalyptus plantation and Poincianella pyramidalis, the wood can be used for commercial purposes to support the economy of local communities (Dias Leme \& Gasson 2012). Therefore, in relation to commercialism of wood product, we asked if wood anatomy of trees originated from seed would be substantially different from that of trees originated from sprouting and whether development would be the same or different. These questions motivated us to investigate the axial variation in six positions along the vertical axis in trees derived from seeds and sprouting after coppicing in $S$. brasiliensis Toledo (Solanaceae).

\section{Materials and Methods}

This study was carried out in the Parque Estadual da Cantareira (PEC), which is located in São Paulo state $\left(23^{\circ} 35^{\prime}\right.$ and $23^{\circ} 45^{\prime} \mathrm{S} / 46^{\circ} 70^{\prime}$ and $\left.46^{\circ} 48^{\prime} \mathrm{W}\right)$, Brazil. The climate is mesothermic with humid, rainy summers and dry winters. The highest mean temperatures occur between January and February at $23^{\circ} \mathrm{C}$ and $22.8^{\circ} \mathrm{C}$, respectively, and the lowest mean temperatures occur in June and July at $16.6^{\circ} \mathrm{C}$ and $16.5^{\circ} \mathrm{C}$, respectively (Leonel et al. 2009). The main vegetation type of PEC is tropical wet forest.

In 2006, trees were cut in area of the PEC where power pylons were being installed. Four years later in 2010, we visited the area and noted natural regeneration of Sessea brasiliensis plants originating from both seeds and from root regrowth after coppicing. Samples of eight young plants approximately four years old were collected: four from sprouting after coppicing, and four from seeds. All samples were removed with their roots intact. As shown in Figure 1, six samples were taken from different axial positions as follows: root (Rt), 20 $\mathrm{cm}$ underneath the soil; transition zone (TZ), area between the soil and trunk base; trunk base (TB), 10 

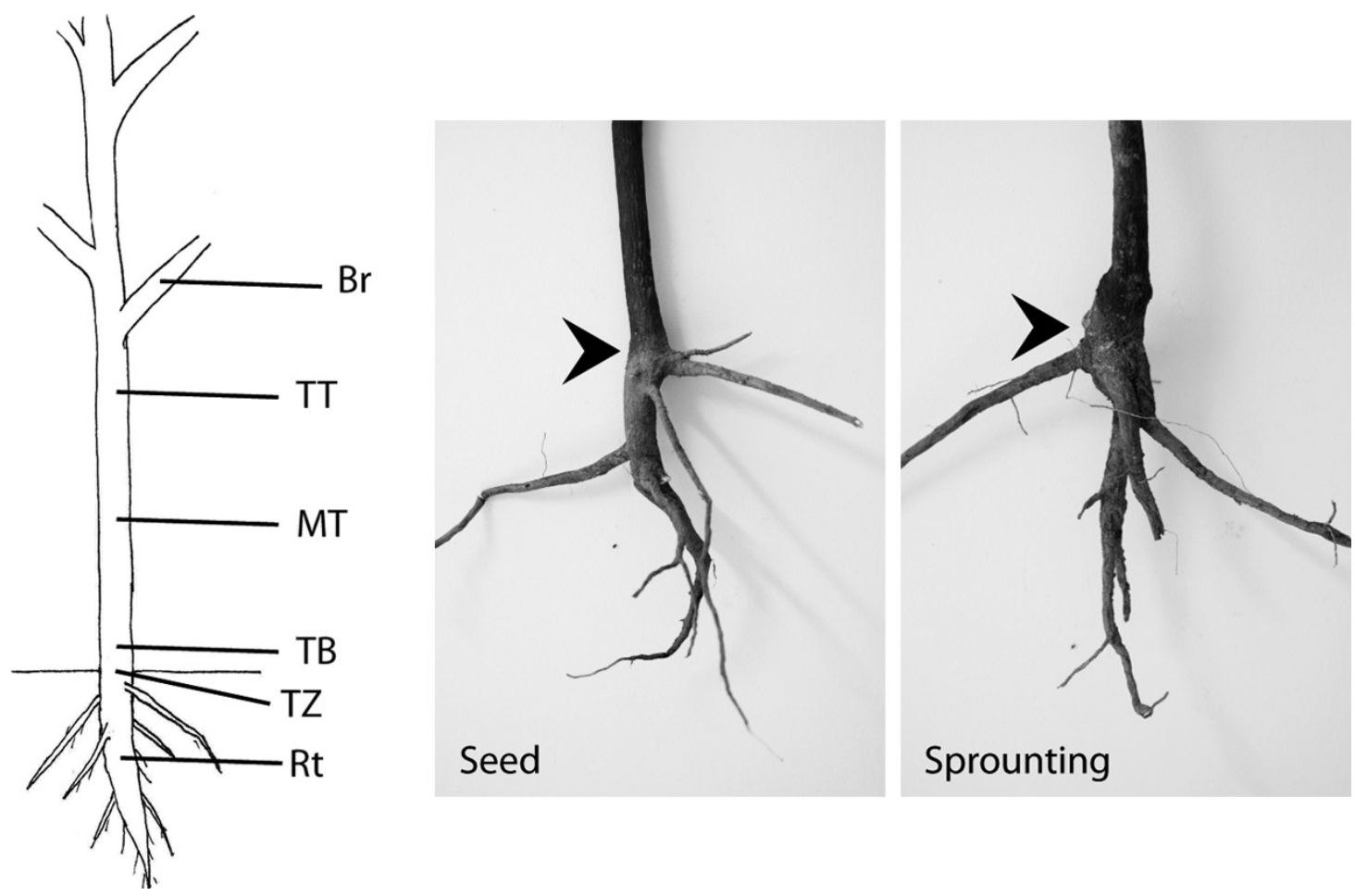

Figure 1 - Schematic illustration and detail of trees originating from seed and sprouting in S. brasiliensis. Notice the differences in morphology (arrowhead). $\mathrm{Rt}=$ Root, $\mathrm{TZ}=$ Transition zone, $\mathrm{TB}=$ Trunk base, $\mathrm{MT}=$ Mid-trunk, $\mathrm{TT}=$ Trunk top and $\mathrm{Br}=\mathrm{Branch}$.

$\mathrm{cm}$ above the soil; mid trunk (MT), excluding the crown; trunk top (TT) under the crown and lowest branch $(\mathrm{Br})$ at the first bifurcation. Tree trunk height varied from 1.8 to $2 \mathrm{~m}$.

Samples approximately $2 \mathrm{~cm}^{3}$ were collected. Sections 12 to $25 \mu \mathrm{m}$ in thickness were obtained with a Zeiss Hyrax S50 slide microtome and stained with aqueous 1\% safranin (Bukatsch 1972). Wood maceration followed the method of Berlyn \& Miksche (1976). Semi-permanent slides were mounted for wood anatomical quantitative analyses, as follows: fiber length, diameter and wall thickness; vessel diameter, frequency and length, as well as intervessel pits and vessel-ray pitting diameter. Twenty-five measurements were taken for each characteristic.

The wood anatomical descriptions followed IAWA (1989). Quantitative data were obtained with Image Pro Plus 6.3 software attached to an Olympus CX 31 microscope.

Hydraulic conductivity was calculated based on vessel diameter, using the following equation: $\mathrm{Kh}$ $=\pi \mathrm{D}^{4} / 128 \eta$, where $\mathrm{D}$ is the diameter, $\eta$ is the viscosity index of water $\left(1.002 \times 10-9 \mathrm{MPa}\right.$ s at $\left.20^{\circ} \mathrm{C}\right)$, and Kh is the hydraulic conductivity (Scholz et al. 2013).
Cell type frequency was calculated using Image Pro Plus 6.3 software, and twenty-five random counts in $1 \mathrm{~mm}^{2}$ were made in each section.

Descriptive statistical analysis and graphing were used to observe the presence of outliers, removing them when necessary. To test anatomical variation in different axial positions, One Way Analysis of Variance (ANOVA) was used, according to normal data distribution. Whenever a significant difference was observed, Tukey tests were carried out for multiple comparisons to identify the determinant pair of differences. Results with $\mathrm{P}<0.05$ were considered significant. In comparisons of axial positions between trees from the two provenances, e.g., root (seed) compared to root (sprouting), the $-t$ test was used. Results with $\mathrm{P}<0.05$ were considered significant.

\section{Results}

Vessels - Comparison of different axial positions (AxP)

Narrower vessels were observed in the transition zone for seed provenance samples and in roots and trunk base for sprouting provenance (Fig. 2, Tab. 1). Shorter vessel elements were observed 

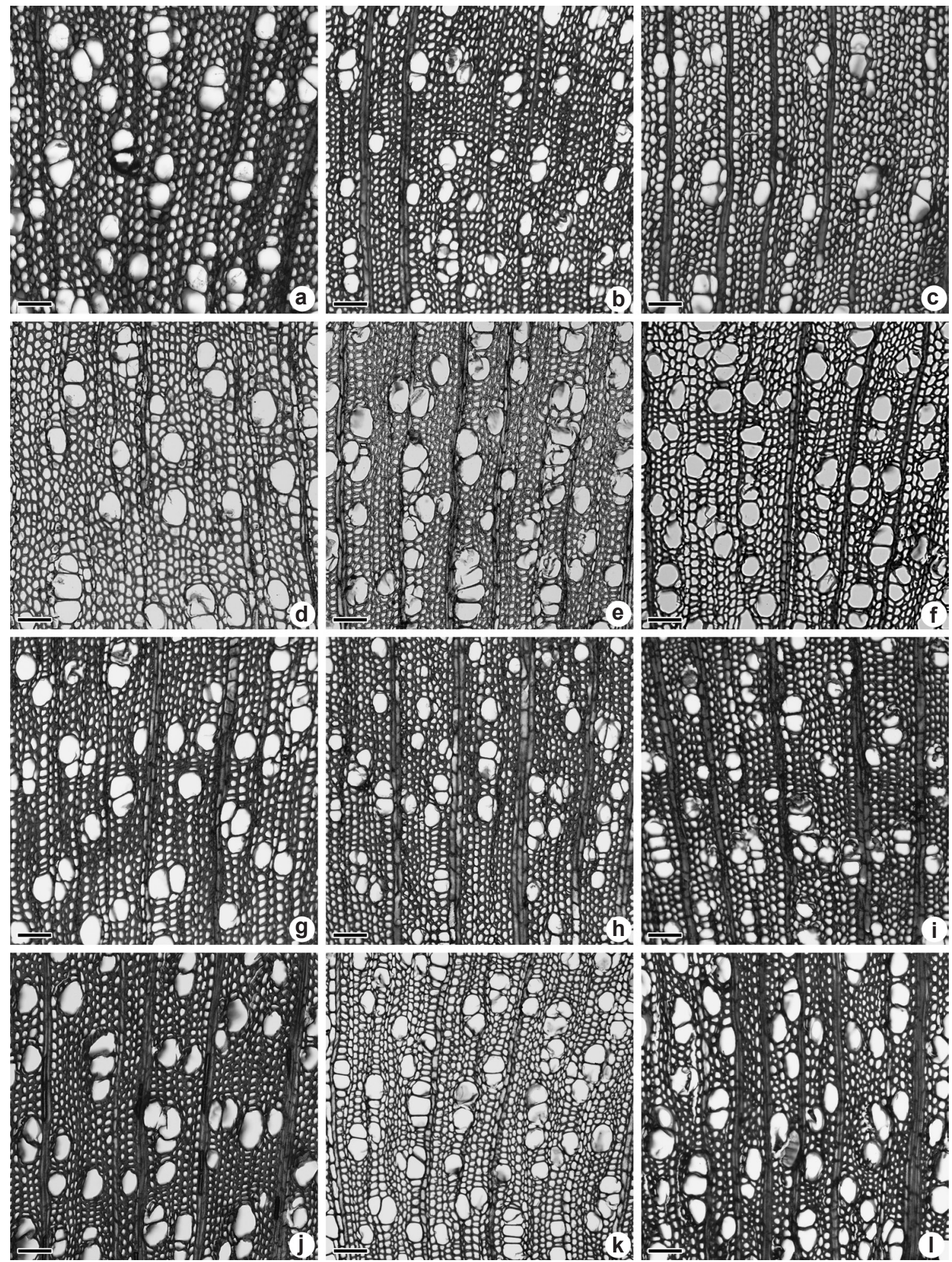

Figure 2 - a-f. Sessea brasiliensis transverse section of seed provenance. - a. root; b. transition zone; c. trunk base; d. mid position of the trunk; e. trunk top; f. branch. g-l. Sessea brasiliensis transverse section of sprouting provenance. - g. root; h. transition zone; i. trunks base; j. mid position of the trunk; k. trunk top; 1. branch. Scale bars $=100 \mu \mathrm{m}$. 
Table 1 - Comparison of vessel features and hydraulic conductivity in relation to axial variation between seed and sprouting samples of Sessea brasiliensis from Parque Estadual Cantareira, São Paulo.

\begin{tabular}{llllllll}
\hline & & Rt & TZ & TB & MT & TT & Br \\
\hline VD & Seed & $52 \mathrm{Aa}$ & $43 \mathrm{Bb}$ & $45 \mathrm{Aa}$ & $46 \mathrm{Aa}$ & $50 \mathrm{Aa}$ & $46 \mathrm{Aa}$ \\
& Sprouting & $45 \mathrm{Bb}$ & $48 \mathrm{Aa}$ & $45 \mathrm{Ab}$ & $49 \mathrm{Aa}$ & $48 \mathrm{Aa}$ & $46 \mathrm{Aa}$ \\
$\mathbf{V E L}$ & Seed & $618 \mathrm{Abc}$ & $589 \mathrm{Bc}$ & $662 \mathrm{Aab}$ & $675 \mathrm{Aab}$ & $645 \mathrm{Babc}$ & $680 \mathrm{Aa}$ \\
& Sprouting & $608 \mathrm{Ab}$ & $647 \mathrm{Aab}$ & $646 \mathrm{Aab}$ & $693 \mathrm{Aa}$ & $693 \mathrm{Aa}$ & $635 \mathrm{Bab}$ \\
$\mathbf{V F}$ & Seed & $37 \mathrm{Ab}$ & $52 \mathrm{Aa}$ & $38 \mathrm{Bb}$ & $43 \mathrm{Bb}$ & $52 \mathrm{Aa}$ & $55 \mathrm{Aa}$ \\
& Sprouting & $33 \mathrm{Ad}$ & $38 \mathrm{Bd}$ & $42 \mathrm{Acd}$ & $60 \mathrm{Aa}$ & $48 \mathrm{Bc}$ & $54 \mathrm{Ab}$ \\
$\mathbf{I P}$ & Seed & $6.3 \mathrm{Bb}$ & $7.0 \mathrm{Aa}$ & $7.6 \mathrm{Aa}$ & $7.2 \mathrm{Aa}$ & $7.1 \mathrm{Aa}$ & $7.3 \mathrm{Aa}$ \\
& Sprouting & $7.8 \mathrm{Aa}$ & $7.2 \mathrm{Aa}$ & $7.2 \mathrm{Aa}$ & $6.9 \mathrm{Aa}$ & $7.3 \mathrm{Aa}$ & $7.2 \mathrm{Aa}$ \\
$\mathbf{K h}$ & Seed & $0.25 \mathrm{Aa}$ & $0.12 \mathrm{Ac}$ & $0.14 \mathrm{Abc}$ & $0.16 \mathrm{Abc}$ & $0.21 \mathrm{Aab}$ & $0.15 \mathrm{Abc}$ \\
& Sprouting & $0.17 \mathrm{Ba}$ & $0.17 \mathrm{Aa}$ & $0.13 \mathrm{Aa}$ & $0.21 \mathrm{Aa}$ & $0.20 \mathrm{Aa}$ & $0.15 \mathrm{Aa}$ \\
\hline
\end{tabular}

$\mathrm{VD}=$ Vessel diameter $(\mathrm{mm}) ; \mathrm{VEL}=$ Vessel element length $(\mathrm{mm}) ; \mathrm{VF}=$ Vessel frequency $\left(\mathrm{n}^{\circ} \mathrm{mm}^{-2}\right) ; \mathrm{IP}=\operatorname{Intervessel}$ pit diameter $(\mathrm{mm}) ; \mathrm{K}=\mathrm{Hydraulic}$ conductivity $\left(\mathrm{m}^{4} / \mathrm{MPa}^{-1} * \mathrm{~s}^{-1}\right)$; Rt $=$ Root; $\mathrm{TZ}=$ Transition zone; TB $=$ Trunk base; $\mathrm{MT}=$ Mid trunk; TT $=$ Trunk top; $\mathrm{Br}=\mathrm{Branch}$. Lowercase: comparison in the different axial positions. Uppercase: comparison of the axial variation between the seed and sprouting. Results with $\mathrm{P}<0.05$ were considered significant; Tukey test for axial variation and $-t$ test for comparison between seed and sprouting.

in roots, transition zone and trunk top in samples from seed origin. The sprouting samples showed the greatest variation of vessel frequency, being higher in mid-trunk and lower in the roots and transition zone. In seed origin samples, transition zone, trunk top and branch showed the highest frequencies (Fig. 2). Intervessel pits only showed difference in roots of seed provenance, being smaller than the other positions. Hydraulic conductivity axially varied only in plants from seed origin (Tab. 1). In addition, vessel grouping varied axially in plants from sprouting. We noted changes in all axial positions, e.g., a decrease in the percentage of solitary vessels in mid-trunk and trunk top, a difference between the multiple of 2 or more vessels between root, and a difference in M3 vessels between root and both mid trunk and trunk top (Tab. 4).

Vessels - Comparison of axial variation between trees of seed and sprouting origins (ASeSp)

Vessel diameter was smaller in plants of seed origin in the transition zone. For plants of sprouting origin, only roots showed smaller vessel diameter (Fig. 2). At transition zone and trunk top, longer vessels occurred in samples that originated from sprouting, while for branches, the vessels were longer in samples that originated from seeds. Vessel frequency showed great variation, and statistical differences were observed in the transition zone, trunk base, mid-trunk and trunk top. High vessel frequency was observed in the transition zone and at trunk top for seed provenance samples, while vessel frequency at trunk base and mid-trunk was higher for sprouting provenance samples (Fig. 2). Intervessel pits were only statistically different for roots, being smaller in seed provenance samples. Hydraulic conductivity varied only in roots, with lower values in plants from sprouting origin (Tab. 1). We highlight lower percentages of solitary vessels in roots and transition zones and higher percentages of M3 and M4 + vessels in plants originated from seeds compared to those derived from sprouting (Tab. 4).

Fibers - Comparison of different axial
positions (AxP)
Sprouting samples had short fibers in roots, trunk base and branch. Fiber diameter was smaller in trunk top and branch of seed and sprouting provenances, respectively. Fibers were narrower in trunk base and branch for both sprouting and seed provenances (Tab. 2). 
Table 2 - Comparison of fiber features in relation to axial variation between seed and sprouting samples of Sessea brasiliensis from Parque Estadual Cantareira, São Paulo.

\begin{tabular}{llllllll}
\hline & & Rt & TZ & TB & MT & TT & Br \\
\hline FL & Seed & $1078 \mathrm{Aa}$ & $1110 \mathrm{Aa}$ & $1142 \mathrm{Aa}$ & $1115 \mathrm{Aa}$ & $1057 \mathrm{Aa}$ & $1032 \mathrm{Aa}$ \\
& Sprouting & $1030 \mathrm{Ab}$ & $1150 \mathrm{Aa}$ & $1059 \mathrm{Ab}$ & $1152 \mathrm{Aa}$ & $1109 \mathrm{Aa}$ & $954 \mathrm{Ab}$ \\
FD & Seed & $38 \mathrm{Aa}$ & $34 \mathrm{Aa}$ & $34 \mathrm{Aa}$ & $35 \mathrm{Aa}$ & $32 \mathrm{Bb}$ & $34 \mathrm{Aa}$ \\
& Sprouting & $38 \mathrm{Aa}$ & $36 \mathrm{Aa}$ & $34 \mathrm{Aa}$ & $33 \mathrm{Aa}$ & $34 \mathrm{Aa}$ & $28 \mathrm{Bb}$ \\
\multirow{2}{*}{ FWT } & Seed & $5.5 \mathrm{Ba}$ & $6.1 \mathrm{Aa}$ & $5.3 \mathrm{Ab}$ & $5.6 \mathrm{Bab}$ & $5.6 \mathrm{Ba}$ & $5.4 \mathrm{Ab}$ \\
& Sprouting & $6.2 \mathrm{Aa}$ & $6.3 \mathrm{Aa}$ & $5.6 \mathrm{Ab}$ & $6.3 \mathrm{Aa}$ & $6.1 \mathrm{Aa}$ & $5.1 \mathrm{Ab}$ \\
\hline
\end{tabular}

$\mathrm{FL}=$ Fiber length $(\mathrm{mm}) ; \mathrm{FD}=$ Fiber diameter $(\mathrm{mm}) ; \mathrm{FWT}=$ Fiber wall thickness $(\mathrm{mm}) ; \mathrm{Rt}=$ Root; TZ = Transition zone; TB = Trunk base; MT = Mid trunk; $\mathrm{TT}=$ Trunk top $\mathrm{Br}=$ Branch. Uppercase: comparison of the axial variation between the seed and sprouting origins. Results with $\mathrm{P}<0.05$ were considered significant; Tukey test for axial variation and $-t$ test for comparison between seed and sprouting.

Fibers - Comparison of axial variation between seed and sprouting origins (ASeSp)

In general, fiber length and diameter were similar between origins. Trunk base and branch had smaller fibers in sprouting samples. Only trunk top of seed provenance and branch of sprouting provenance were statistically different and showed small diameter when compared to each other. In sprouting samples, the fiber walls were thicker in root, mid-trunk and trunk top (Tab. 2).

Rays - Comparison of the different axial positions (AxP)

In seed samples, higher rays were observed in branch and trunk top. In the sprouting samples, higher rays also were observed in branch and trunk top, but from there downward, a clear trend was observed (Tab. 3; Fig. 3).
Rays - Comparison of axial variation between the seed and sprouting origins (ASeSp)

This feature was practically unchanged between origins since only mid-trunk position was lower in sprouting sample compared to the seed sample (Tab. 3; Fig. 3).

Cell type frequencies (\%) Comparison of the different axial positions (AxP)

Vessel percentage increased from the roots up to the branches for plants of seed provenance, whereas for sprouting samples, variation occurred within the tree. Fiber percentage decreased gradually from root to branch in seed samples, while in sprouting samples, the values were more homogeneous, with less percentage between mid-trunk and branch. Percentage of rays

Table 3 - Comparison of ray features in relation to axial variation between seed and sprouting samples of Sessea brasiliensis from the Parque Estadual Cantareira, São Paulo.

\begin{tabular}{|c|c|c|c|c|c|c|c|}
\hline & & Rt & $\mathbf{T Z}$ & TB & MT & TT & $\mathrm{Br}$ \\
\hline \multirow[t]{2}{*}{ RH } & Seed & $433 \mathrm{Ac}$ & $439 \mathrm{Ac}$ & $433 \mathrm{Ac}$ & $445 \mathrm{Abc}$ & $529 \mathrm{Aab}$ & $574 \mathrm{Aa}$ \\
\hline & Sprouting & 396 Acd & $343 \mathrm{Bd}$ & $385 \mathrm{Bcd}$ & $439 \mathrm{Abc}$ & $480 \mathrm{Aab}$ & $509 \mathrm{Aa}$ \\
\hline \multirow[t]{2}{*}{ RW } & Seed & $66 \mathrm{Aa}$ & $58 \mathrm{Ab}$ & $49 \mathrm{Ac}$ & $49 \mathrm{Ac}$ & $41 \mathrm{Ad}$ & $41 \mathrm{Ad}$ \\
\hline & Sprouting & $64 \mathrm{Aa}$ & $60 \mathrm{Aa}$ & $51 \mathrm{Ab}$ & $41 \mathrm{Bc}$ & $41 \mathrm{Ac}$ & $44 \mathrm{Ac}$ \\
\hline
\end{tabular}

$\mathrm{RH}=$ Ray height $(\mathrm{mm}) ; \mathrm{RW}=$ Ray width $(\mathrm{mm}) ; \mathrm{Rt}=$ Root; $\mathrm{TZ}=$ Transition zone; $\mathrm{TB}=$ Trunk base; $\mathrm{MT}=\mathrm{Mid}$ trunk; $\mathrm{TT}=\mathrm{Trunk}$ top; $\mathrm{Br}=\mathrm{Branch}$. Lowercase: comparison in the different axial positions. Uppercase: comparison of axial variation between samples from seed and sprouting origins. Results with $\mathrm{P}<0.05$ were considered significant; Tukey test for axial variation and $-t$ test for comparison between seed and sprouting. 

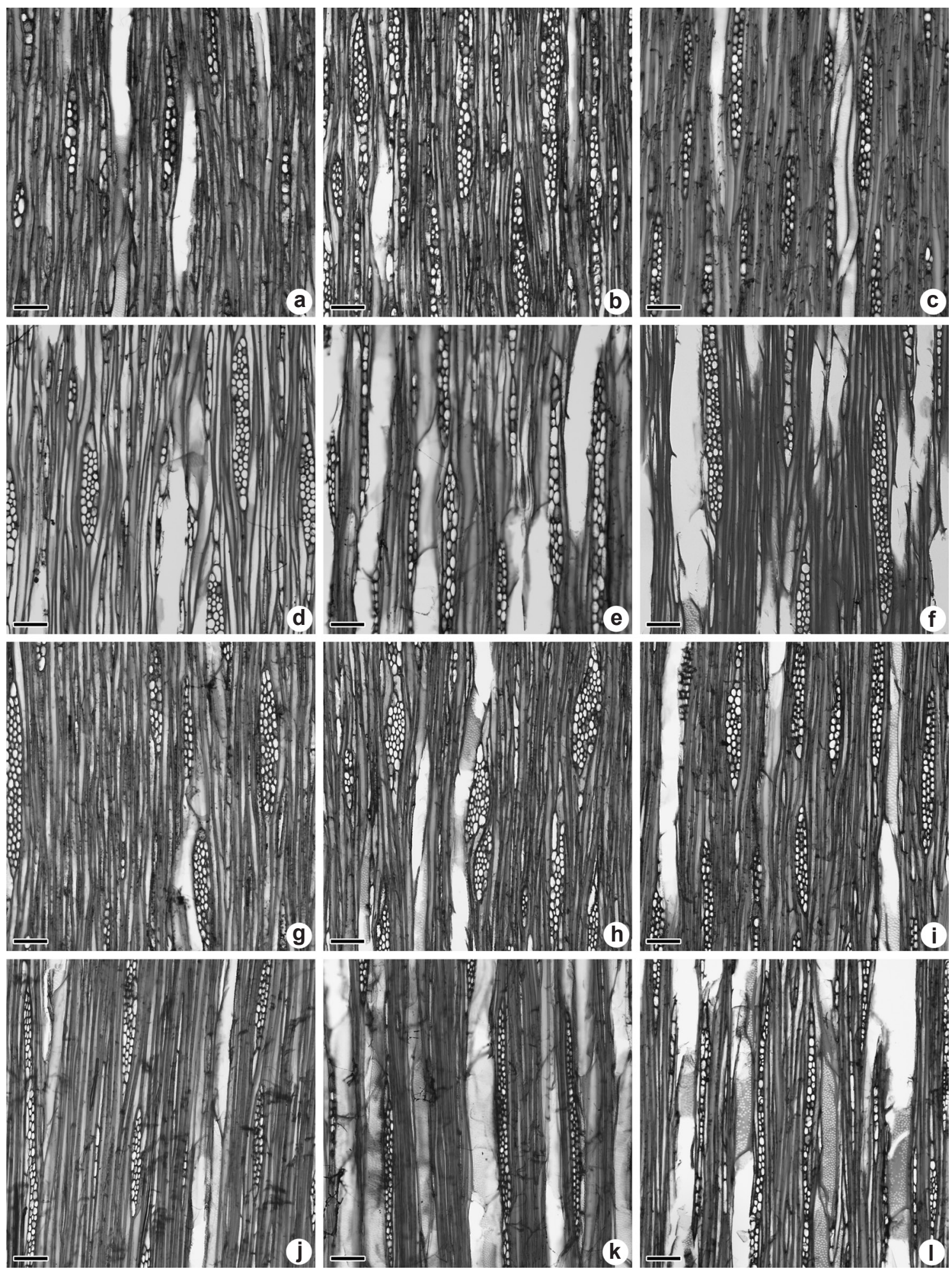

Figure 3 - a-f. Sessea brasiliensis tangential section of seed provenance. - a. root; b. transition zone; c. trunk base; d. mid position of the trunk; e. trunk top; f. branch. g-l. Sessea brasiliensis tangential section of sprouting provenance. - g. root; h. transition zone; i. trunk base; j. mid position of the trunk; k. trunk top; 1. branch. Scale bars $=100 \mu \mathrm{m}$. 
Table 4 - Variation in vessel grouping (\%) from root to branch in Sessea brasiliensis from Parque Estadual Cantareira, São Paulo.

\begin{tabular}{|c|c|c|c|c|c|c|c|}
\hline & & Rt & TZ & TB & MT & TT & $\mathrm{Br}$ \\
\hline \multirow[t]{2}{*}{$\mathbf{S}$} & Seed & $54 \mathrm{Ba}$ & $51 \mathrm{Ba}$ & $55 \mathrm{Aa}$ & $57 \mathrm{Aa}$ & $55 \mathrm{Aa}$ & $53 \mathrm{Ba}$ \\
\hline & Sprouting & $63 \mathrm{Aa}$ & $59 \mathrm{Aab}$ & $58 \mathrm{Aab}$ & $53 \mathrm{Ab}$ & $57 \mathrm{Ab}$ & $60 \mathrm{Aab}$ \\
\hline \multirow[t]{2}{*}{ M2 } & Seed & $32 \mathrm{Aa}$ & $33 \mathrm{Aa}$ & $31 \mathrm{Aa}$ & $30 \mathrm{Ba}$ & $33 \mathrm{Aa}$ & $32 \mathrm{Aa}$ \\
\hline & Sprouting & $29 \mathrm{Ab}$ & $31 \mathrm{Aab}$ & $31 \mathrm{Aab}$ & $34 \mathrm{Aa}$ & $30 \mathrm{Aab}$ & $30 \mathrm{Aab}$ \\
\hline \multirow[t]{2}{*}{ M3 } & Seed & $9 \mathrm{Aa}$ & $11 \mathrm{Aa}$ & $11 \mathrm{Aa}$ & $10 \mathrm{Aa}$ & $9 \mathrm{Aa}$ & $11 \mathrm{Aa}$ \\
\hline & Sprouting & $6 \mathrm{Bb}$ & $7 \mathrm{Bab}$ & $8 \mathrm{Bab}$ & $9 \mathrm{Aa}$ & $10 \mathrm{Aa}$ & $7 \mathrm{Bab}$ \\
\hline \multirow[t]{2}{*}{ M4 } & Seed & $4 \mathrm{Aa}$ & $5 \mathrm{Aa}$ & $3 \mathrm{Aa}$ & $3 \mathrm{Aa}$ & $3 \mathrm{Aa}$ & $4 \mathrm{Aa}$ \\
\hline & Sprouting & $2 \mathrm{Ba}$ & $2 \mathrm{Ba}$ & $2 \mathrm{Aa}$ & $3 \mathrm{Aa}$ & $3 \mathrm{Aa}$ & $3 \mathrm{Aa}$ \\
\hline
\end{tabular}

Lowercase: comparison among the different axial positions. $\mathrm{S}=$ solitary vessels; $\mathrm{M} 2=$ multiple of 2 vessels; M3 = multiples of 3 vessels; M4+ = multiples of 4 or more vessels; Rt $=$ Root; $\mathrm{TZ}=$ Transition zone; $\mathrm{TB}=$ Trunk base; $\mathrm{MT}=$ Mid trunk; $\mathrm{TT}=$ Trunk top; $\mathrm{Br}=\mathrm{Branch} ; \mathrm{se}=\mathrm{seed}$ provenance; $\mathrm{sp}=\mathrm{sprouting}$ provenance. Lowercase: comparison in the different axial positions. Uppercase: comparison of axial variation between the seed and sprouting. Results with $\mathrm{P}<$ 0.05 were considered significant; Tukey test for axial variation and - $t$ test for comparison between seed and sprouting.

oscillated from root to branch in samples of both provenances, but in a more regular manner in seed samples (Tab. 5; Fig. 2).

Cell type frequencies (\%) - Comparison of axial variation between seed and sprouting origins (ASeSp)

In sprouting samples, a small proportion of vessels were found in the transition zone and trunk top when compared with seed samples. Fiber percentage was greater in roots from seed provenance. A higher percentage of rays were found in sprouting provenance for most positions (Tab. 5; Fig. 2).

\section{Discussion}

Vessel frequency of $S$. brasiliensis showed a great variation between seed and sprouting provenances when comparing axial positions, while in studies with Quercus velutina and Eriotheca gracilipes, Stokke \& Manwiller (1994) and Longui et al. (2012), respectively, reported a gradual increase in vessel frequency from roots to branches, indicating that frequency may vary according to species and environments with different accessibility to water.

Coppicing also influenced vessel grouping, with lower percentages of solitary vessels in roots and transition zone, but higher percentages of M3

Table 5 - Cell type frequencies (\%) between seed and sprouting samples of Sessea brasiliensis from Parque Estadual Cantareira, São Paulo.

\begin{tabular}{|c|c|c|c|c|c|c|c|}
\hline & & $\mathbf{R t}$ & $\mathbf{T Z}$ & TB & MT & TT & $\mathrm{Br}$ \\
\hline \multirow[t]{2}{*}{$\mathbf{V}$} & Seed & $12 \mathrm{Ac}$ & $15 \mathrm{Ac}$ & $13 \mathrm{Ac}$ & $24 \mathrm{Ab}$ & $28 \mathrm{Aab}$ & $32 \mathrm{Aa}$ \\
\hline & Sprouting & 13 Ade & $9 \mathrm{Be}$ & 17 Acd & $28 \mathrm{Aa}$ & $21 \mathrm{Bbc}$ & $27 \mathrm{Aab}$ \\
\hline \multirow[t]{2}{*}{$\mathbf{F}$} & Seed & $81 \mathrm{Aa}$ & $74 \mathrm{Aab}$ & $75 \mathrm{Aab}$ & $68 \mathrm{Abc}$ & $65 \mathrm{Ac}$ & $56 \mathrm{Ad}$ \\
\hline & Sprouting & $71 \mathrm{Ba}$ & $71 \mathrm{Aa}$ & $71 \mathrm{Aa}$ & $62 \mathrm{Ab}$ & $64 \mathrm{Aab}$ & $61 \mathrm{Ab}$ \\
\hline \multirow[t]{2}{*}{$\mathbf{R}$} & Seed & $7 \mathrm{Bab}$ & $11 \mathrm{Bab}$ & $12 \mathrm{Aa}$ & $9 \mathrm{Aab}$ & $7 \mathrm{Bb}$ & $11 \mathrm{Aa}$ \\
\hline & Sprouting & $16 \mathrm{Aab}$ & $20 \mathrm{Aa}$ & $12 \mathrm{Abc}$ & $10 \mathrm{Ac}$ & $15 \mathrm{Aabc}$ & $12 \mathrm{Abc}$ \\
\hline
\end{tabular}

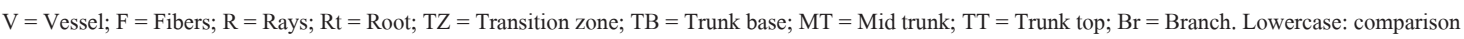
in the different axial positions. Uppercase: comparison of the axial variation between the seed and sprouting. Results with $\mathrm{P}<0.05$ were considered significant; Tukey test for axial variation and $-t$ test for comparison between seed and sprouting. 
and M4+ vessels in plants originating from seed compared to those from sprouting. According to Tyree \& Zimmermann (2002), multiple vessels in higher proportion are safer than solitary vessels inasmuch as they provide alternative paths for water transport. Thus, plants from sprouting provenance in both root and transition zones showed more efficient, but less safe, wood for transporting water, which may reflect an effort to recover the shoot.

Short vessel elements were observed in high frequency in the transition zone, trunk top, and branch in seed provenance samples when comparing axial positions. Also, narrow vessels (less than $50 \mu \mathrm{m}$ ) were observed in all positions, except in roots. Areas with larger vessels and high frequency tend to increase hydraulic potential, but decrease resistance to embolism (Baas et al. 2004; Hacke et al. 2005). In our case, this was true for roots, which also have a lower percentage of vessels. However, according to Baas et al. (2004) and Tyree \& Zimmermann (2002), a minor risk of air bubble formation would be noted in the other axial positions (transition zone, trunk top, branch).

Root wood with wider vessels is typically more vulnerable to embolism (Baas 1982; Gasson 1985; Ewers et al. 1997; Machado et al. 1997; Psaras \& Sofroniou 2004). However, in our study, $S$. brasiliensis samples had narrow vessels with low frequency of roots from sprouting provenance when compared with the trunk and branch throughout the different axial positions. Also, when comparing the different provenances, narrow vessels were found in roots of samples from sprouting provenance, but not in samples from seed provenance. In the absence of experimental studies, it is likely that the clear-cutting may have had some effect on hormonal production in $S$. brasiliensis in accordance with Dayan et al. (2012) who reported that "decapitation" mainly depletes auxin, which affects cambial activity and vascular development. Moreover, Zimmermann (1983) and Hacke \& Sperry (2001) report that hydraulic stress in roots is less than that observed in trunks, which are less likely to develop embolism based on the positive pressure in roots that could make air bubbles more easily reversible. Nevertheless, it is important to emphasize that little is known about how roots and trunk function relative to differences in mechanical requirements of the whole tree or the mechanical properties of tissue (ChristensenDalsgaard et al. 2007).
In S. brasiliensis root sprouts, vessel diameter increased from root to transition zone, whereas in seed samples, vessel diameter decreased. This phenomenon in seed samples is consistent with the segmentation hypothesis, as proposed by Tyree \& Zimmermann (2002), which holds that narrower vessels at nodal zones may confine embolism. Also, a small proportion of vessels were found in the transition zone of sprouting samples when compared with seed samples of $S$. brasiliensis.

In the case of $S$. brasiliensis, the production of auxin may have been stimulated by coppicing, consequently causing an increase in vessel diameter in the transition region (transition zone) in sprouting samples, if only because the source of auxin production, i.e., young leaves, was pulled with the shoot plant. According to Aloni (2007), auxin hormone descending from young leaves to root tips produces narrow vessels that differentiate near the young leaves where the highest auxin concentrations are expected, while the widest vessels are formed in the roots at the greatest distance from the sources of auxin.

Arbellay et al. (2012) reported that wounding induces the formation of narrower vessels following stem cambial injury as a result of duration and extension of anatomical changes in wood structure. In S. brasiliensis, it is possible that the mechanisms of stem recovery in relation to vessel diameter differ from those of root since an increase in vessel diameter in the transition region (transition zone), as well as a small proportion of vessels in sprouting.

According to Christensen-Dalsgaard et al. (2007), the differences in mechanical properties might reflect differences in conductivity along the roots, but the authors still observed that roots had a lower conductivity and higher strength than the trunk. When comparing different axial positions, we observed in root samples of sprouting provenance thick-walled fibers and narrow vessels in low frequency, showing a tradeoff between more safety, as a result of mechanical stiffness in the hydraulic system, and less efficiency in conduction.

When comparing different axial positions in plants of seed origin, we noticed a bottleneck in vessel diameter in the transition zone from roots to trunk. This could represent a security adaptation in water conduction whereby, according to Hacke et al. (2005), such vessel tapering could help avoid air bubble formation by diminishing the 
risk of embolism. Our group previously found the presence of bottlenecks in the transition from root to stem in five native species of the Cerrado, including Anadenanthera peregrina, Copaifera langsdorffii, Handroanthus ochraceus, Ocotea corymbosa and Xylopia aromatica (unpublished data).

Moreover, in the transition zone, a greater quantity of ray cells in seed origin was observed when comparing provenances and within the tree. This occurrence could be seen as important, as the parenchyma cells which are found adjacent to an embolized vessel could refill it (Nardini et al. 2011), consequently diminishing the risk of not functional vessels in this area.

Coppicing changed the pattern of hydraulic conductivity, as noted in sprouting samples that did not vary axially, while those originating from seeds showed a decrease in Kh from root to transition zone and from trunk top to branch. Also, in sprouting samples a small proportion of vessels were found in the transition zone and trunk top when compared with seed samples. We do not have a concrete explanation for this result, it can be speculated that it is related to the changes in wood caused by the action of hormones, as discussed above.

Intervessel pits only showed difference in roots of seed provenance when comparing different axial positions, which was smaller than the other positions. When comparing provenances, intervessel pits were only statistically different for roots, being smaller pits in samples from seed origin. To understand the effect of pits on safety and resistance of vessels, more detailed measurements and studies are required for such parameters as pit structure, size of aperture, total area of pits, or thickness and porosity of membrane (see Jansen et al. 2009; Wheeler et al. 2005).

When comparing different axial positions of sprouting provenance (AV), fibers were shorter in roots, trunk base and branch with thin walls in the last two positions. When comparing different provenances, fibers were shorter in the trunk base and branch and thicker in roots, mid-trunk and trunk tops of sprouting samples. Thus, it could be hypothesized that coppicing in sprouting samples resulted in short fibers in root and trunk base since, according to Dayan et al. (2012), defoliation causes growth retardation and depletion of gibberellin (GA) production, which specifically induces fiber formation. Another theory would suggest that thicker fiber walls found in roots in sprouting provenance may have resulted from the cessation of vascular cambium activities after being cut, essentially because wood density is negatively associated with growth rate (Enquist et al. 1999).

Since growth is normalized in sprouting samples when comparing different axial positions, we observed a similar fiber length and thickness in the mid trunk and trunk top positions and a decrease in branches, also the lowest percentage of fibers occurred in branches of seeds provenance. These features at these positions are responsible for mechanical support (Evert \& Eichhorn 2006); therefore, this configuration is to be expected in that mechanical resistance should generally be higher in this area. Greater flexibility is also expected in branch and trunk base since fibers are structured to allow the trunk to resist gravitational forces and keep, or restore, the original trunk orientation (Barnett \& Jeronimidis 2003).

Axially, ray height did not change the pattern between seed and sprouting provenance, with lower rays in the transition zone and trunk base of the plants from sprouting provenance and higher rays in trunk top and branch. Ray width decreased toward the branch for both origins, but the plants from sprouting origin showed a delay in this response because the transition zone did not differ from root or ray percentage. This delay may have happened because of the coppicing. Following wounding or coppicing, Lev-Yadun \& Aloni (1995) and Aloni et al. (2000) reported that ethylene gas induces the development of vascular rays by promoting cell divisions in the cambial fusiform initials and the enlargement of existing rays.

\section{Conclusion}

In young Sessea brasiliensis treelets, wood originated from sprouting after coppicing develops differently from wood originating from seed provenance, thus confirming the hypothesis that quantitative variation in anatomical features in the axial direction indicates adjustments in water conductivity and mechanical strength along tree height, as determined by observation of axial variations in vessels, fibers and rays. Also, the observation of significant differences between provences, likely caused by hormonal changes in response to coppicing, confirms the hypothesis that significant quantitative differences would be observed in anatomical features between trees originating from seed when compared to those sprouting after coppicing. 


\section{Acknowledgments}

We are grateful to Sonia Godoy Campião and Diego Romeiro, for laboratory assistance.

\section{References}

Aloni, R. 2007. Phytohormonal mechanisms that control wood quality formation in young and mature trees. In: Entwistle, K.; Harris, P. \& Walker, P. (eds.). The compromised wood workshop. The wood technology research centre. University of Canterbury, Christchurch. Pp. 1-22.

Aloni, R.; Feigenbaum, P.; Kalev, N. \& Rozovsky S. 2000. Hormonal control of vascular differentiation in plants: the physiological basis of cambium ontogeny and xylem evolution. In: Savidge, R.A.; Barnett, J.R. \& Napier, R. (eds.). Cell and molecular biology of wood formation. BIOS Scientific Publishers, Oxford. Pp. 223-236.

Aloni, R. 2010. The induction of vascular tissue by auxin. In: Davies, P.J. (ed.). Plant hormones: biosynthesis, signal transduction. Action! Revised. $3^{\text {rd }}$ ed. Kluwer Academic Publishers, Dordrecht, Boston, London. Pp. 485-506.

Anfodillo, T.; Petit, G. \& Crivellaro, A. 2013. Axial conduit widening in woody species: a still neglected anatomical pattern. IAWA Journal 34: 352-364.

Arbellay, E.; Fonti, P. \& Stoffel, M. 2012. Duration and extension of anatomical changes in wood structure after cambial injury. Journal of Experimental Botany 63: 3271-3277.

Arzolla, F.A.R.D.P. 2011. Florestas secundárias e a regeneração natural de clareiras antrópicas na Serra da Cantareira, SP. Tese de Doutorado em Biologia Vegetal. Instituto de Biologia. Universidade Estadual de Campinas, São Paulo. 141 p.

Baas, P. 1982. Systematic, phylogenetic, and ecological wood anatomy. In: Baas, P. (ed.). New perspectives in wood anatomy. Nijhoff/Junk, The Hague. Pp. 23-58.

Baas, P.; Ewers, F.W.; Davis, S.D. \& Wheeler, E.A. 2004. Evolution of xylem physiology. In: Poole, I. \& Hemsley, A. (eds.). Evolution of plant physiology. Linnean Society Symposium Series. Elsevier Academic Press, London. Pp. 273-295.

Barnett, J.R. \& Jeronimidis, G. 2003. Reaction wood. In: Barnett, J.R. \& Jeronimidis, G. (eds.). Wood quality and its biological basis. Blackwell Publishing Ltd., Oxford. Pp. 118-136.

Berlyn, G.P. \& Miksche, J.P. 1976. Botanical microtechnique and cytochemistry. The Iowa University Press, Iowa. 326p.

BFG. 2015. Growing knowledge: an overview of Seed Plant diversity in Brazil. Rodriguésia 66: 1085-1113.

Bukatsch, F. 1972. Bermerkungen zur Doppelfärbung Astrablau-Safranin. Mikrokosmos 61: 255.

Canella, F.C.C.; Tokarnia, C.H. \& Dobereiner, J. 1968. Intoxicação por Sessea brasiliensis Toledo em bovinos. Pesquisa Veterinária Brasileira 3: 333-340.
Carlquist, S. 1988. Comparative wood anatomy: systematic, ecological, and evolutionary aspects of dicotyledonous wood. Springer-Verlag, New York. 436p.

Carlquist, S. \& Hoekman, D.A. 1985. Ecological wood anatomy of the woody southern Californian flora. IAWA Bull 6: 319-347.

Castellani, T.T. \& Stubblebine, W.H. 1993. Sucessão secundária em mata tropical mesófila, após perturbação por fogo. Revista Brasileira de Botânica 16: 181-203.

Choat, B.; Cobb, A.R. \& Jansen, S. 2008. Structure and function of bordered pits: new discoveries and impacts on whole-plant hydraulic function. New Phytologist 177: 608-626.

Christensen-Dalsgaard, K.K.; Ennos, A.R. \& Fournier, M. 2007. Changes in hydraulic conductivity, mechanical properties, and density reflecting the fall in strain along the lateral roots of two species of tropical trees. Journal of Experimental Botany 58: 4095-4105.

Dayan, J.; Voronin, N.; Gong, F.; Sun, T.; Hedden, P.; Fromm, H. \& Aloni, R. 2012. Leaf-induced gibberellin signaling is essential for internode elongation, cambial activity, and fiber differentiation in tobacco stems. The Plant Cell 24: 66-79.

Dias Leme, C.L. \& Gasson, P. 2012. Anatomical comparison of original and regrowth wood from coppiced and pollarded Poincianella pyramidalis trees in the Caatinga of Pernambuco, Brazil. IAWA Journal 33: 63-72.

Enquist, B.J.; West, G.B.; Chernov, E.L. \& Brown, J.H. 1999. Allometric scaling of production and life history variation in vascular plants. Nature 401: 907-911.

Evert, R.F. \& Eichhorn, S.E. 2006. Esau's plant anatomy: meristems, cells, and tissues of the plant body: their structure, function, and development. $3^{\text {rd }}$ ed. WileyLiss, New Jersey. 624p.

Ewers, F.W.; Carlton, M.R.; Fisher, J.B.; Kolb, K.J. \& Tyree, M.P. 1997. Vessel diameters in roots versus stems of tropical lianas and other growth forms. IAWA Journal 18: 261-279.

Gasson, P.E. 1985. Automatic measurement of vessel lumen area and diameter with particular reference to pendunculate oak and common beach. IAWA Bulletin 6: 219-237.

Goulart, S.L. \& Marcati, C.R. 2008. Anatomia comparada do lenho em raiz e caule de Lippia salviifolia Cham. (Verbenaceae). Revista Brasileira de Botânica 2: 263-275.

Hacke, G. \& Sperry, J.S. 2001. Functional and ecological xylem anatomy. In: Hacke, U.G. \& Sperry, J.S. (eds.). Perspectives in plant ecology, evolution and systematics. Vol. 4/2. University of Utah, Salt Lake. Pp. 97-115.

Hacke, U.G.; Sperry, J.S. \& Pittermann, J. 2005. Efficiency versus safety tradeoffs for water 
conduction in angiosperm vessels versus gymnosperm tracheids. In: Holbrook, M.N. \& Zwienniecki, M.A. (eds.). Vascular transport in plants. Elsevier Inc, Amsterdam. Pp. 333-354.

Hacke, U.G.; Sperry, J.S.; Wheeler, J.K. \& Castro, L. 2006. Scaling of angiosperm xylem structure with safety and efficiency. Tree Physiology 26: 689-701.

IAWA Committee. 1989. IAWA list of microscopic features for hardwood identification. IAWA Bulletin 10: 219-332.

Jacobsen, A.L.; Ewers, F.W.; Pratt, R.B.; Paddock, W.A. \& Davis, S.D. 2005. Do xylem fibers affect vessel cavitation resistance? Plant Physiology 149: 546-556.

Jansen, S.; Choat, B. \& Pletsers, A. 2009. Morphological variation of intervessel pit membranes and implications to xylem function in angiosperms. American Journal of Botany 96: 409-419.

Kammesheidt, L. 1998. The role of tree sprouts in the restorations of stand structure and species diversity in tropical moist forest after slash-and-burn agriculture in Eastern Paraguay. Plant Ecology 139: $155-165$.

Leonel, C. 2009. Parque Estadual da Cantareira resumo executivo. Fundação Florestal, Secretaria do Meio Ambiente de São Paulo. 75p. Available at <http://www.fflorestal.sp.gov.br/media/ uploads/planosmanejo/PECantareira/Resumo $\% 20$ Executivo/0.\%20Resumo\%20Executivo.pdf $>$. Acessed on 28 May 2012.

Lev-Yadun, S. \& Aloni, R. 1995. Differentiation of the ray system in woody plants. Botanical Review 61: 45-84.

Longui, E.L.; Silva, R.A.B.G.; Romeiro, D.; Lima, I.L.; Florsheim, S.M.B. \& Melo, A.C.G. 2012. Root-branch anatomical investigation of Eriotheca gracilipes young trees: a biomechanical and ecological approach. Scientia Forestalis 40: 23-33.

Machado, S.R.; Angyalossy-Alfonso, V. \& Morretes, B.L. 1997. Comparative wood anatomy of root and stem in Styrax camporum (Styracaceae). IAWA Journal 8: 13-25.

Machado, S.R.; Rodella, R.A.; Angyalossy, V. \& Marcati, C.R. 2007. Structural variations in root and stem wood of Styrax (Styracaceae) from Brazilian forest and cerrado. IAWA Journal 28: 173-188.

Martínez-Cabrera, H.I.; Jones, C.S.; Espino, S. \& Schenk, H.J. 2009. Wood anatomy and wood density in shrubs: responses to varying aridity along transcontinental transects. American Journal of Botany 96: 1388-1398.
Nardini, A.; Lo Gullob, M.A. \& Salleo, S. 2011. Refilling embolized xylem conduits: is it a matter of phloem unloading? Plant Science 180: 604-611.

Negrelle, R.R.B. 1995. Sprouting after uprooting of canopy trees in the Atlantic rain forest of Brazil. Biotropica 27: 448-454.

Psaras, G.K. \& Sofroniou, I. 2004. Stem and root wood anatomy of the shrub Phlomis fruticosa (Labiatae). IAWA Journal 25: 71-77.

Rodrigues, R.R.; Torres, R.B.; Matthes, L.A.F; Penha, A.S. 2004. Tree species sprouting from root buds in a semideciduous forest affected by fires. Brazilian Archives of Biology and Technology 47: 127-133.

Scholz, A.; Klepsch, M.; Karimi, Z. \& Jansen, S. 2013. How to quantify conduits in wood? Frontiers in Plant Science 4: 1-11.

Sperry, J.S.; Hacke, U.G.; Pittermann, J. 2006. Size and function in conifer tracheids and angiosperm vessels. American Journal of Botany 93: 14901500 .

Stokes, A. \& Guitard, D. 1997. Tree root response to mechanical stress. In: Altman, A. \& Waisel, Y. (eds.). Biology of root formation and development. Plenum Press, New York. Pp. 227-236.

Stokke, D.D. \& Manwiller, F.G. 1994. Proportions of wood elements in stem, branch, and root wood of black oak (Quercus velutina). Forestry Sciences 3: 301-310.

Tyree, M.T. \& Zimmermann, M.H. 2002. Xylem structure and the ascent of sap. Springer Verlag, Berlin. 283p.

Van Bloem, S.J.; Murphy, P.G. \& Lugo, A.E. 2007. A link between hurricane-induced tree sprouting, high stem density, and short canopy in tropical dry forest. Tree Physiology 27: 475-480.

Wheeler, J.K.; Sperry, J.S.; Hacke, U.G. \& Hoang, N. 2005. Inter-vessel pitting and cavitation in woody Rosaceae and other vesselled plants: a basis for a safety versus efficiency trade-off in xylem transport. Plant, Cell \& Environment 28: 800-812.

Zimmermann, M.H. 1978. Structural requirements for optimal water conduction in tree stems. In: Tomlinson, P.B. \& Zimmermann, M.H. (eds.). Tropical trees as living systems. Cambridge University Press, Cambridge. Pp. 517-537.

Zimmermann, M.H. 1983. Xylem structure and the ascent of sap. Springer-Verlag, New York. 143p.

Zwieniecki, M.A.; Melcher, P.J.; Holbrook, N.M. 2001. Hydraulic properties of individual xylem vessels of Fraxinus americana. Journal of Experimental Botany 52: 257-264. 